\title{
Mass balance and ice flow along the north-northwest ridge of the Greenland ice sheet at NorthGRIP
}

\author{
Christine Sahøtt HVIDberG, ${ }^{1}$ Kristian Keller, ${ }^{2}$ Niels S. GUNDESTRUP ${ }^{1}$ \\ ${ }^{1}$ Niels Bohr Institute, Department of Geophysics, University of Copenhagen, Juliane Maries Vej 30, DK-2100 Copenhagen, Denmark \\ E-mail: ch@gfy.ku.dk \\ ${ }^{2}$ National Survey and Cadastre (KMS), Rentemestervej 8, DK-2400 Copenhagen, Denmark
}

\begin{abstract}
The North Greenland Icecore Project (NorthGRIP) deep drilling site $\left(75^{\circ} 05^{\prime} 47^{\prime \prime} \mathrm{N}, 42^{\circ} 19^{\prime} 42^{\prime \prime} \mathrm{W}\right)$ is located at the north-northwest ridge of the Greenland ice sheet, $320 \mathrm{~km}$ from Summit. A strain net has been established around the NorthGRIP site and surveyed with global positioning system. Our results show that ice flows with a horizontal surface velocity of $1.329 \pm 0.015 \mathrm{~m} \mathrm{a}^{-\mathrm{r}}$ along the ridge. Estimated principal surface strain rates at NorthGRIP are $\dot{\varepsilon}_{1}=(-0.4 \pm 0.6) \times 10^{-5} \mathrm{a}^{-1}$ and $\dot{\varepsilon}_{2}=(7.1 \pm 0.6) \times 10^{-5} \mathrm{a}^{-1}$, in the directions along and transverse to the north-northwest ridge, respectively, i.e. ice is compressed along the ridge but stretched transverse to the ridge. Possible implications of the observed flow pattern for the stratigraphy are discussed. The average thickening rate in the strain-net area is found to be $\partial H / \partial t=0.00 \pm 0.04 \mathrm{~m} \mathrm{a}^{-1}$, in agreement with previous estimates of mass balance in high-elevation areas of Greenland.
\end{abstract}

\section{INTRODUGTION}

As part of the North Greenland Ice Core Project (NorthGRIP) deep drilling programme, an ice core is presently being drilled in North Greenland at $75^{\circ} 05^{\prime} 47^{\prime \prime} \mathrm{N}, 42^{\circ} 19^{\prime} 42^{\prime \prime} \mathrm{W}$ (Dahl-Jensen and others, 2002). The NorthGRIP deep drilling site is located at the north-northwest ridge, $320 \mathrm{~km}$ from Summit (Fig. 1).

Between 1996 and 2001, a strain net consisting of 44 stakes was established around a reference pole at the NorthGRIP site. The strain net has been positioned repeatedly with global positioning system (GPS). The strain-net stakes were placed at distances of up to about $50 \mathrm{~km}$ from the drill site, and cover $100 \mathrm{~km}$ along the ridge. From the GPS survey, surface velocities are determined at the stakes, and principal surface strain rates at the NorthGRIP site are calculated.

The surface strain-net data contribute to knowledge of the flow pattern at NorthGRIP and may be used to constrain calculations of stress fields and thinning of layers in the core. We discuss the flow pattern along the north-northwest ridge and possible implications for the stratigraphy in the NorthGRIP core. The discussion is based on the surface strain-net data from NorthGRIP, and on similar data obtained around Summit during the Greenland Icecore Project (GRIP) deep drilling programme (Hvidberg and others, 1997b).

As well as GPS data, observations of accumulation rate and ice thickness are also available in the NorthGRIP region. These allow the mass balance of the Greenland ice sheet at NorthGRIP to be estimated from the equation of continuity, and the calculated rate of ice-thickness change is compared with recent estimates of mass balance in Greenland.

\section{REGION OF STUDY}

Surface topography of the northern part of the Greenland ice sheet has been mapped based on Geosat and European Remote-sensing Satellite-1 (ERS-1) satellite data (Ekholm, 1996). A section of the Greenland ice sheet, covering both Summit and the NorthGRIP site, is shown in Figure 1.

The flowline from Summit to NorthGRIP follows the north-northwest ridge. The flow pattern changes along the flowline. From Summit to about $73.5^{\circ} \mathrm{N}(125 \mathrm{~km}$ from Summit), the flowline intersects surface contour lines which are organized in a concentric pattern with gradually decreasing curvature, as in axial-symmetric flow. From $73.5^{\circ} \mathrm{N}$, the flow pattern changes as the north-northwest ridge gradually stands out. Between $74.5^{\circ}$ and $76^{\circ} \mathrm{N}$ (about 225-400 km from Summit), the direction of the ridge is about $-15^{\circ}$ from north, the surface descends along the ridge with a constant slope of $-0.7 \mathrm{~m} \mathrm{~km}^{-1}$, and the flow is highly divergent, with a constant curvature (radius approximately $25 \mathrm{~km}$ ) of the surface contour lines. Near $77^{\circ} \mathrm{N}$ ( $550 \mathrm{~km}$ from Summit), the ridge divides into two. West of the north-northwest ridge, the ice sheet slopes more steeply towards the western margin of the ice sheet in an almost two-dimensional pattern. East of the ridge, the ice sheet slopes northeastwards.

\section{GPS SURVEY OF STRAIN NET}

\section{Surface strain net}

The NorthGRIP strain net was established between 1996 and 1999, and consisted of a total of 44 stakes plus a reference pole (Fig. 2). The reference pole was established in 1997, $500 \mathrm{~m}$ west of the NorthGRIP drill site, by fixing a $102 \mathrm{~m}$ aluminium pole with a steel base into a $98.6 \mathrm{~m}$ deep hole. The reference pole replaced a semi-deep $(10 \mathrm{~m})$ preliminary reference pole set up in 1996. Sixteen stakes were installed in 1996 in two concentric circles with radii of approximately 10 and $50 \mathrm{~km}$, respectively, centred around the preliminary reference pole. In 1997, 16 


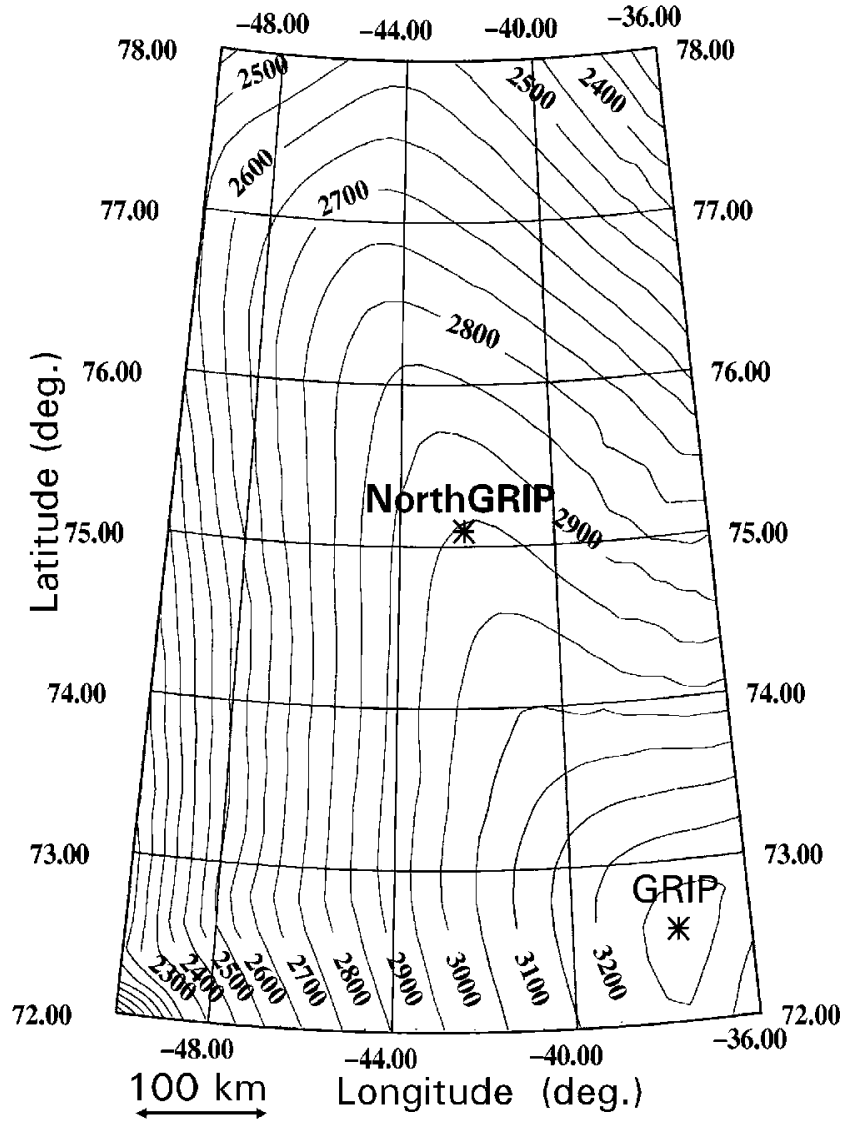

Fig. 1. Surface topography map of the central part of the Greenland ice sheet north of $72^{\circ} \mathcal{N}$ (ellipsoidal height; Ekholm, 1996). Deep drilling locations are indicated by asterisks: GRIP at $72.59^{\circ} \mathcal{N}, 38.46^{\circ} \mathrm{W}$, and NorthGRIP at $75.10^{\circ} \mathcal{N}, 42.32^{\circ} \mathrm{W}$. The distance between GRIP and NorthGRIP is $320 \mathrm{~km}$.

stakes were installed in a strain net within $6-7 \mathrm{~km}$ of the reference pole. In 1998, 12 stakes were installed in four groups of three, placed along the ridge with spacings of $10 \mathrm{~km}$ upstream from the reference pole, towards the GRIP site at Summit.

The NorthGRIP deep-fixed reference pole was positioned with static GPS in 1997, 1998, 1999 and 2001. (The semi-deep preliminary reference pole was used in 1996.) Each year, several 24 hour sessions of GPS data were processed with the Bernese software in a network with four GPS reference stations (Thule, Kelly Ville (Kangerlussuaq/Sondrestrom), Reykjavík and Ny Ålesund; in 2001, Thule was replaced by the modernized GPS station, Thule 2, also located at Thule Air Base), using precise orbits and an ionospheric-free

Table 1. Position of the reference pole at NorthGRIP. The height is measured as the height above the World Geodetic System 1984 (WGS84) ellipsoid. The geoid height of $37.65 \mathrm{~m}$ subtracted from the ellipsoidal height gives a height above mean sea level of $2917.7 \mathrm{~m}$

Year, day Location Height $\begin{array}{cc}\text { Ant. } \\ \text { height }\end{array} \begin{gathered}\text { Surf. } \\ \text { height }\end{gathered}$

m m m

$1997,21075^{\circ} 05^{\prime} 47.03509^{\prime \prime} \mathrm{N}, 42^{\circ} 19^{\prime} 41.44134^{\prime \prime} \mathrm{W} \quad 2959.30 \quad \mathrm{~N} / \mathrm{A} \quad \mathrm{N} / \mathrm{A}$ $1998,17275^{\circ} 05^{\prime} 47.06699^{\prime \prime} \mathrm{N}, 42^{\circ} 19^{\prime} 41.52453^{\prime \prime} \mathrm{W} \quad 2959.13 \quad 3.62 \quad 2955.51$ $1999,157 \quad 75^{\circ} 05^{\prime} 47.10123^{\prime \prime} \mathrm{N}, 42^{\circ} 19^{\prime} 41.61434^{\prime \prime} \mathrm{W} \quad 2958.97 \quad 3.57 \quad 2955.40$ 2001, $16975^{\circ} 05^{\prime} 47.17436^{\prime \prime} \mathrm{N}, 42^{\circ} 19^{\prime} 41.80589^{\prime \prime} \mathrm{W} \quad 2958.51 \quad 3.16 \quad 2955.35$
Table 2. Annual movement of the reference pole at NorthGRIP. The mean annual movement is $1.329 \pm 0.015 \mathrm{ma}^{-1}$ northwestwards

\begin{tabular}{lccccc}
\hline Years & Latitude & Longitude & $\begin{array}{c}\text { Height } \\
\mathrm{cm}\end{array}$ & $\begin{array}{c}\text { Ant. height } \\
\mathrm{cm}\end{array}$ & $\begin{array}{c}\text { Surface } \\
\mathrm{cm}\end{array}$ \\
\hline $1997-98$ & $109.7 \mathrm{~cm} \mathrm{~N}$ & $74.1 \mathrm{cmW}$ & -15.9 & $\mathrm{~N} / \mathrm{A}$ & $\mathrm{N} / \mathrm{A}$ \\
$1998-99$ & $109.1 \mathrm{~cm} \mathrm{~N}$ & $73.2 \mathrm{cmW}$ & -18.9 & -5.0 & -11.0 \\
$1999-2001 *$ & $110.8 \mathrm{~cm} \mathrm{~N}$ & $75.1 \mathrm{cmW}$ & -22.6 & -20.5 & -2.5 \\
Mean & $110.1 \mathrm{~cm} \mathrm{~N}$ & $74.4 \mathrm{cmW}$ & -20.0 & -15.3 & -5.3 \\
\hline
\end{tabular}

* These data are mean values over 2 years.

solution with float ambiguities. All processing was carried out in the appropriate time epoch, and after that, yearly solutions were transformed back to the International Terrestrial Reference Frame 94 (ITRF94) (epoch 15-08-1997) using Thule as the only fixed station. Thus, we were able to minimize geodynamic influence in our data. The movement observed between two years was corrected for the length of the measurement period in order to obtain the annual movement over 365 days. The observed positions and the derived annual surface movements at NorthGRIP are listed in Tables 1 and 2, respectively. The mean annual surface movement at NorthGRIP is $1.329 \pm 0.015 \mathrm{~m} \mathrm{a}^{-1}$ in the northwest direction. The observed mean change in height is consistent with the observed thickness of an annual layer at $100 \mathrm{~m}$ depth, $0.195 \mathrm{~m}$ (personal communication from H. B. Clausen, 2001)

\section{GPS survey and results}

Each year, the strain-net stakes were occupied using static GPS, organized into groups with local position periods of approximately $30 \mathrm{~min}$ for baselines up to $10 \mathrm{~km}$, and of 1-3 hours for positioning stakes further away from the control site. Surface velocities of the stakes relative to the reference pole were determined from the repeated occupations (Fig. 3). Uncertainties in the relative velocity estimates depend on the precision of the repeated occupations and the GPS processing. Our estimates of the uncertainty range from $0.02 \mathrm{~m} \mathrm{a}^{-1}$ for the very precise short baselines, to $0.30 \mathrm{~m} \mathrm{a}^{-1}$ for the poorest-positioned stakes at distances of up to $80 \mathrm{~km}$ from the control site. The GPS data were processed using standard processing software GPSurvey ver. 2.35 from Trimble, including precise orbit data and an ionospheric-free fixed or float solution. Surface velocities (Fig. 2) are perpendicular to the surface contour lines. They are almost constant along the ridge, and increase with distance from the ridge. The highest velocities are west of the ridge, where the surface slope increases.

\section{OTHER DATA}

Several other glaciological data exist in the NorthGRIP region. Ice thickness and accumulation are needed to calculate the mass balance, and ice temperature must be known in order to model the variation of velocity with depth.

\section{Ice thickness}

Airborne radar measurements of ice thickness in central and North Greenland have been compiled to give ice thickness along the north-northwest ridge from Summit to NorthGRIP (Dahl-Jensen and others, 1997) (Fig. 4). The 


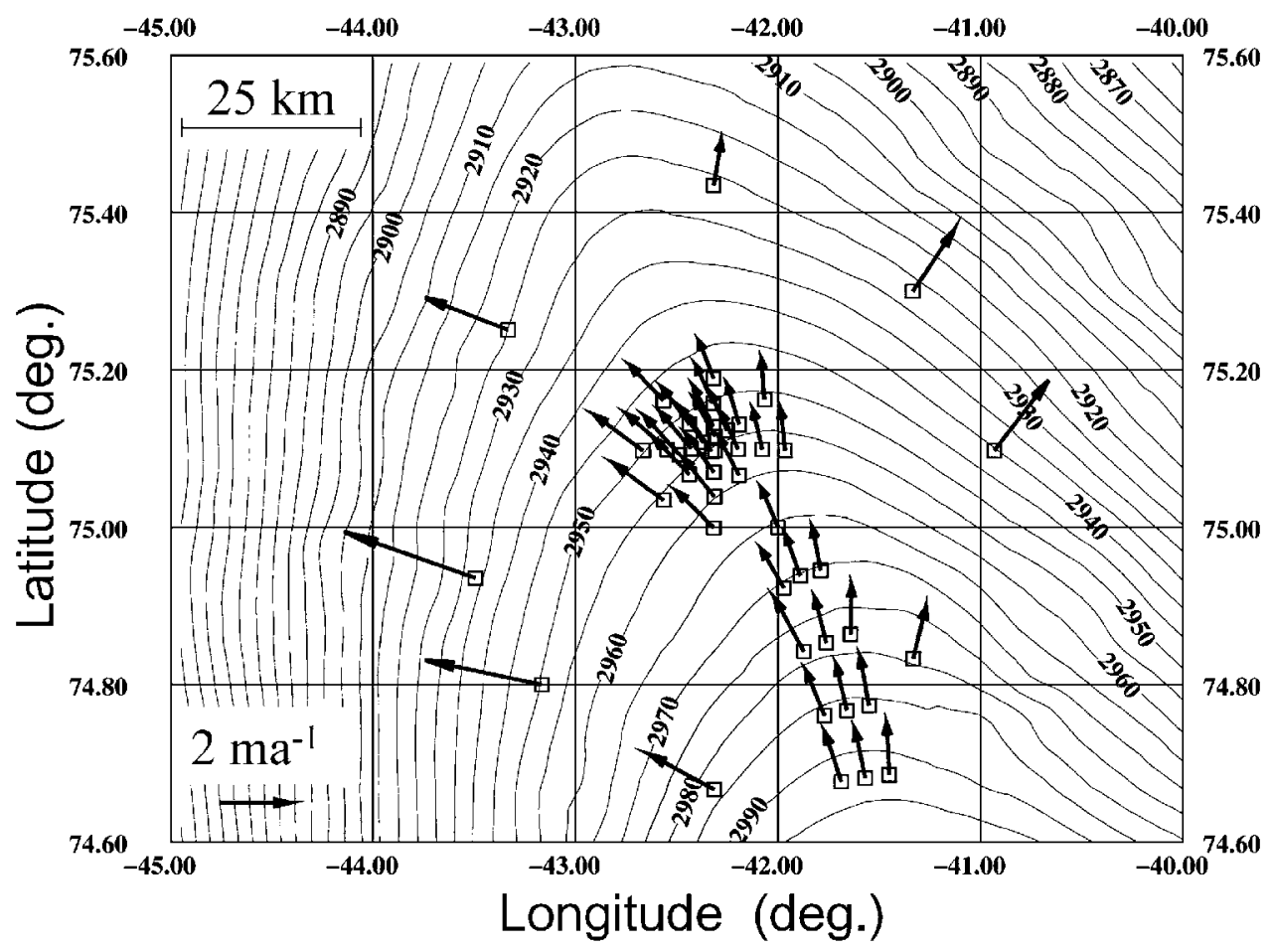

Fig. 2. Observed surface velocity at 44 stakes around the NorthGRIP site. Arrow length is scaled according to the measured surface velocity ( scale in lower left corner), and the direction indicates flow direction. Stakes are marked by open squares. The NorthGRIP reference pole (not marked) is located in the centre of stakes at position $75.10^{\circ} \mathcal{N}, 42.30^{\circ} \mathrm{W}$, and has a surface velocity of $1.329 \pm 0.015 \mathrm{ma}^{-1}$.

bedrock is smooth in the strain-net area, with variations of $<50 \mathrm{~m}$. The ice thickness at NorthGRIP is $3085 \mathrm{~m}$ with an accuracy of $\pm 50 \mathrm{~m}$. Density measurements on the NorthGRIP core show a content of $25 \mathrm{~m}$ of air in the firn (personal communication from H.B. Clausen, 2001), giving an ice equivalent thickness of $3060 \mathrm{~m}$ ice.

\section{Accumulation rate}

The accumulation rate and vertical strain rate have been determined in the NorthGRIP core by identified volcanic reference horizons in the electrical conductivity record of the ice core. The accumulation rate between 1783 (the Laki

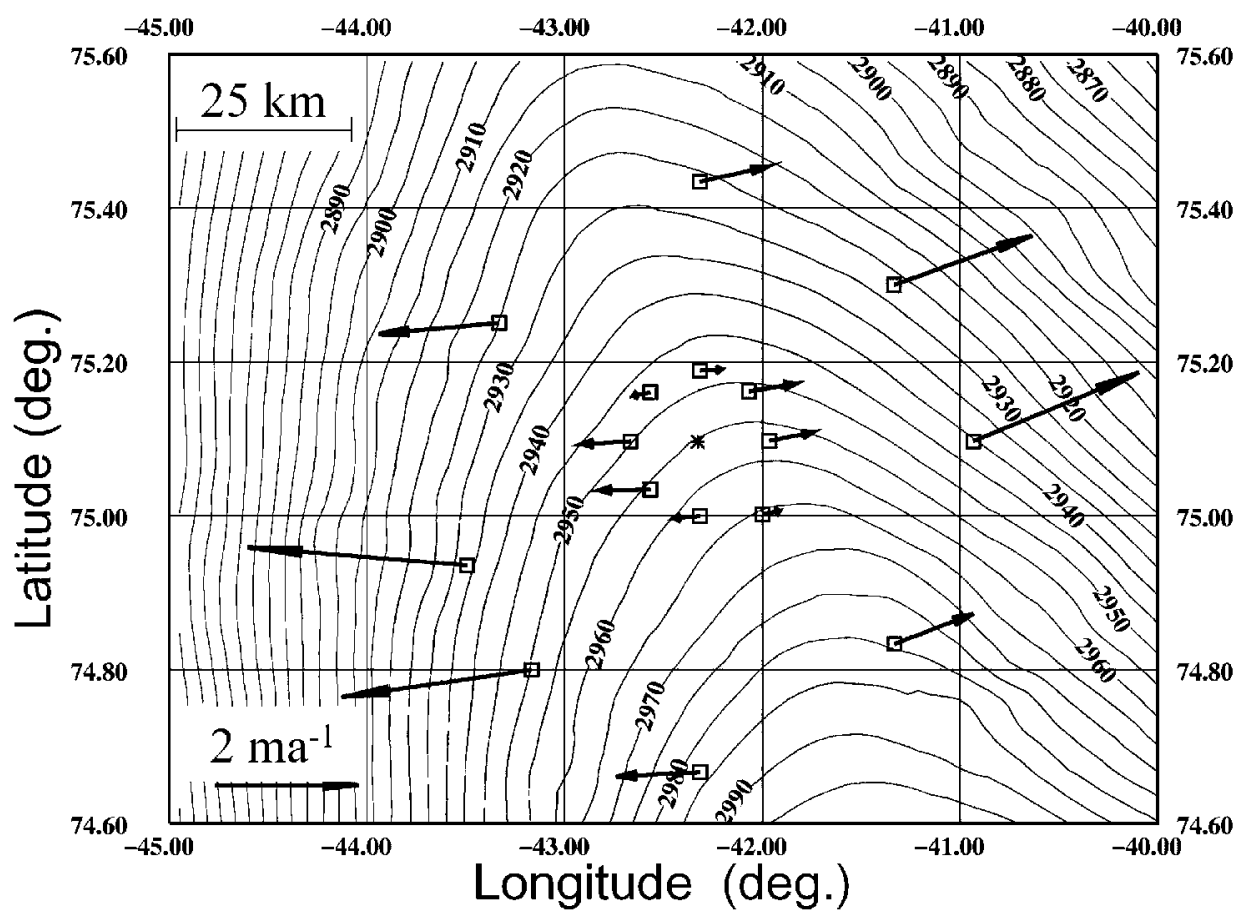

Fig. 3. Surface velocity at the stakes relative to the reference pole (asterisk). Arrow length is scaled according to the measured relative surface velocity ( scale in lower left corner), and the direction indicates direction of flow relative to the reference pole. Stakes are marked by open squares. For clarity, only data from 16 stakes are shown. These stakes are located in approximate circles around the reference pole with radii of 10 and $50 \mathrm{~km}$. 


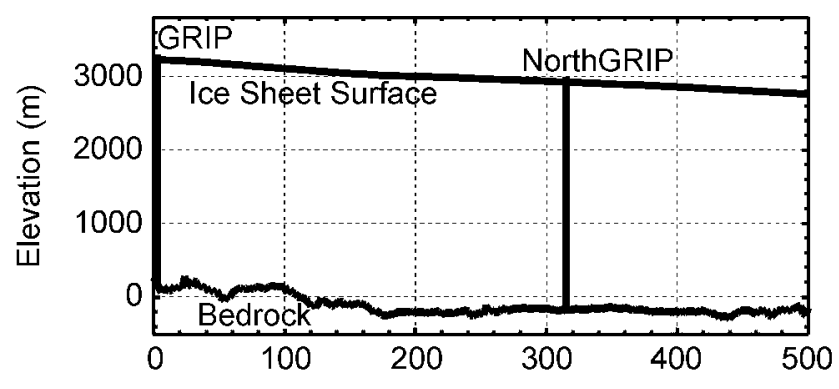

Distance from Summit along NNW ridge $(\mathrm{km})$

Fig. 4. Observed surface and bedrock topography along the flowline from Summit along the north-northwest ridge, passing the GRIP site (3 km from the topographic dome) and the NorthGRIP site (320 km from Summit). Data are compiled by Dahl-fensen and others (1997).

(Iceland) volcanic eruption) and 1996 is $0.188 \mathrm{~m}$ ice equiva-

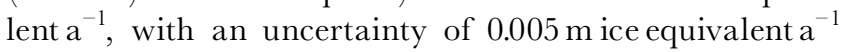
(personal communication from H. B. Clausen, 2001). Previously, the accumulation rate in North Greenland has been determined from shallow cores, and average rates over 4000 years have been derived from internal radio-echo layers along the north-northwest ridge (Dahl-Jensen and others, 1997). These data agree with the accumulation rate determined from the NorthGRIP ice core, and they consistently show that the accumulation rate has been unchanged over several thousand years.

\section{Ice temperature}

The mean annual surface temperature at NorthGRIP is $-31.5^{\circ} \mathrm{C}$. The bottom temperature is not yet known, but preliminary logging of the drillhole points to a temperature close to the pressure-melting point of $-2.4^{\circ} \mathrm{C}$ (assuming a rate of change of melting point of $-8.5 \times 10^{-8} \mathrm{~K} \mathrm{~Pa}^{-1}$ (Paterson, 1994, p. 212) and an ice thickness of $3060 \mathrm{~m}$ ice equivalent) (DahlJensen and others, 2002).

\section{APPLICATION OF DATA}

\section{Principal surface strain rates}

At the reference pole, horizontal principal surface strain rates are determined from the surface velocity data. This is done by calculating the radial strain rate for each stake, and determining the best-fit sine to the variation of the radial strain rates vs the direction to the stake from the reference pole. The principal strain rates are $\dot{\varepsilon}_{1}=(-0.4 \pm 0.6) \times 10^{-5} \mathrm{a}^{-1}$ and $\dot{\varepsilon}_{2}=(7.1 \pm 0.6) \times 10^{-5} \mathrm{a}^{-1}$ (uncertainty given as twice the standard deviation). The principal axes are in directions $\theta_{1}=-15^{\circ}$ from north, and $\theta_{2}=75^{\circ}$ from north, i.e. the first principal axis coincides with the direction of the ridge. The sum of the principal surface strain rates, $\dot{\varepsilon}_{1}+\dot{\varepsilon}_{2}=$ $(6.6 \pm 0.9) \times 10^{-5} \mathrm{a}^{-1}$ balances (within the uncertainty) the average vertical strain rate in the upper part of the ice at NorthGRIP which is found to be $\dot{\varepsilon}_{z}=-7.36 \times 10^{-5} \mathrm{a}^{-1}$ based on a preliminary time-scale for the NorthGRIP ice core (Johnsen and others 2001; personal communication from S.J. Johnsen, 2001). The strain rate along the ridge is negative, and one order of magnitude smaller than the strain rate transverse to the ridge. This result shows that ice flows along the north-northwest ridge with an almost constant, but slightly decreasing velocity, i.e. the flow is slowed down as it moves along the ridge. The flow is divergent, and vertical compression is almost balanced by horizontal stretching transverse to the ridge, but there is a small horizontal compression along the ridge.

\section{Mass balance}

The local mass balance at NorthGRIP is estimated from the continuity equation, which combines observations of ice thickness, accumulation rate, surface velocity and strain rates at the NorthGRIP site. The vertical variation of horizontal velocity is modelled with an ice-flow model, which takes into account divergence of the flow.

We introduce a horizontal $(x-y)$ coordinate system, with the $x$ axis following the flowline in the direction of the flow. In this coordinate system, the continuity equation may be written (derived from Paterson, 1994, p. 257)

$$
\frac{\partial H}{\partial t}=b+b^{\prime}-f\left[H\left(\dot{\varepsilon}_{1}+\dot{\varepsilon}_{2}\right)+u_{s} \frac{\partial H}{\partial x}\right],
$$

where $H$ is ice thickness (in m ice equivalent), $t$ is time, $b$ is the surface accumulation rate (in mice equivalent $\mathrm{a}^{-1}$ ), $b^{\prime}$ is the bottom melting (negative, in $\mathrm{m}$ ice equivalent $\mathrm{a}^{-1}$ ), $f$ is the velocity shape factor, defined as $f=u_{\mathrm{m}} / u_{\mathrm{S}}$, where $u_{\mathrm{m}}$ is the vertically averaged horizontal velocity, $u_{\mathrm{S}}$ is the horizontal surface velocity in the $x$ direction, and $\dot{\varepsilon}_{1}+\dot{\varepsilon}_{2}$ is the sum of the horizontal principal surface strain rates. It is assumed that the velocity shape factor does not change along the flowline.

The vertical variation of the horizontal velocity is derived from an ice-flow model (Hvidberg, 1996; Hvidberg and others, 1997a). The model is based on Glen's flow law, and simulates the thermomechanically coupled ice and heat flow along a flowline. The model includes longitudinal stresses, and takes into account divergence of the flow. Shear stresses transverse to the flowline are disregarded. It is assumed that the direction of the flow does not change with depth, that the flowline is perpendicular to the surface contour lines, and that divergence of the flow may be expressed in terms of the radius of curvature of surface contour lines at their intersection with the flowline. The model simulates the flow along a flowline departing from Summit and running along the north-northwest ridge. The flowline passes the GRIP and NorthGRIP sites (Fig. 1). The model is based on the topography data shown in Figure 4, and radii of curvature of surface contours along the flowline are derived from Figure 1. The velocity shape factor at NorthGRIP is calculated to be $f=0.88$. This calculation assumes a bottom temperature close to the pressure-melting point, but no bottom sliding. The calculation of $f$ is sensitive to the distribution of temperature with depth, in particular to the bottom conditions, which determine whether the ice is frozen to the bed or sliding. Assuming that bottom sliding accounts for $50 \%$ of the observed surface velocity, and the relative variation of velocity due to ice deformation is as above, the shape factor would be 0.94 . Based on this, we estimate the uncertainty of $f$ to be 0.06 due to the unknown bottom conditions. The shape factor is also affected by changes in longitudinal stresses (stretching or compression) along the flowline (discussed by, e.g., Reeh 1988). Bedrock topography or changes in the divergence of the flow would introduce longitudinal stress gradients. Along the north-northwest ridge at NorthGRIP, however, the divergence is constant, the horizontal surface velocity is almost constant, the surface slope is constant, and the bedrock is 
almost horizontal. Therefore, we neglect a possible contribution to the uncertainty of $f$ from longitudinal stress gradients.

The mass balance of the Greenland ice sheet at NorthGRIP is now estimated from the continuity equation (1) by applying the following values: $H=3060 \pm 50 \mathrm{~m}$ ice equivalent, $b=0.188 \pm 0.005 \mathrm{~m}$ ice equivalent $\mathrm{a}^{-1}, b^{\prime}=-0.002 \pm 0.002 \mathrm{~m}$ ice equivalent $\mathrm{a}^{-1}, \quad u_{\mathrm{S}}=1.329 \pm 0.015 \mathrm{~m} \mathrm{a}^{-1},\left(\dot{\varepsilon}_{1}+\dot{\varepsilon}_{2}\right)=$ $(6.6 \pm 0.9) \times 10^{-5} \mathrm{a}^{-1}, \quad \partial H / \partial x=-0.7 \times 10^{-3}$, and $f=0.94$ \pm 0.06 . The result is:

$$
\frac{\partial H}{\partial t}=0.00 \pm 0.04 \mathrm{~m} \mathrm{a}^{-1}
$$

assuming sliding accounts for $50 \%$ of the ice movement, and a bottom melting of $2 \mathrm{~mm} \mathrm{a}^{-1}$, as suggested by analysis of ice-core data (Grinsted and Dahl-Jensen, 2002). If ice is frozen to the bed with no sliding or melting, $f=0.88$ and $b^{\prime}=0$, the result is $\partial H / \partial t=0.01 \pm 0.04 \mathrm{~m} \mathrm{a}^{-1}$. The uncertainty of $\partial H / \partial t$ is dominated by the uncertainty of the surface strain rates and the uncertainty of $f$.

\section{DISGUSSION}

\section{Strain rates: implications for stratigraphy at North- GRIP}

Surface strain rates contribute to knowledge of the flow and may be used to constrain ice-flow models. The flow pattern at NorthGRIP is complicated for several reasons: (1) ice flow along the north-northwest ridge is highly divergent; (2) bottom melting may occur at NorthGRIP or upstream along the ridge as suggested by preliminary ice-core measurements (Dahl-Jensen and others, 2002; Grinsted and Dahl-Jensen, 2002) and analysis of internal radio-echo layers (Dahl-Jensen and others, 1997); and (3) the bottom temperature at NorthGRIP is expected to be close to the pressure-melting point based on preliminary temperature logging in the borehole down to $80 \mathrm{~m}$ above the bed (DahlJensen and others, 2002). Below, we use strain-rate data to discuss the influence of these complications on the stratigraphy at NorthGRIP.

In a previous survey, surface velocities were measured around Summit (Hvidberg and others, 1997b). The GRIP site was found to be $3 \mathrm{~km}$ from the topographic dome, with a surface velocity of $0.25 \pm 0.06 \mathrm{~m} \mathrm{a}^{-1}$ in the northwest direction. At a stake located $33.4 \mathrm{~km}$ from GRIP in the direction of the flowline between GRIP and NorthGRIP, the surface velocity was measured to be $1.62 \pm 0.11 \mathrm{~m} \mathrm{a}^{-1}$ in the northwest direction. The average compressive strain rate along the ridge between this stake and NorthGRIP is $-1.0 \times 10^{-6} \mathrm{a}^{-1}$. This is lower in magnitude than the strain rate observed at NorthGRIP, and the data imply that the horizontal surface velocity must reach a maximum between the two positions. A simple calculation assuming axial-symmetrical flow within $125 \mathrm{~km}$ of Summit (this is realistic according to the description in the "Region of study" section above), an average accumulation rate of $0.20 \mathrm{~m}$ ice equivalent $\mathrm{a}^{-1}$ (DahlJensen and others, 1997) and an ice thickness of $3000 \mathrm{~m}$ yields a depth-averaged horizontal velocity of $4.2 \mathrm{~m} \mathrm{a}^{-1} 125 \mathrm{~km}$ from Summit. At a distance of about $150 \mathrm{~km}$ from Summit $\left(73.5^{-}-74^{\circ} \mathrm{N}\right)$, the divergence of the flow increases, and the flow is probably slowed down rapidly as the flowline passes the transition to the north-northwest ridge, where the surface slope is small. From a distance of about $200 \mathrm{~km}$ from Summit $\left(74-74.5^{\circ} \mathrm{N}\right)$, the divergence remains constant along the flowline until north of NorthGRIP. A rapid reduction in the ice-flow rate at $150-200 \mathrm{~km}$ from Summit implies enhanced stretching transverse to the ridge, with unknown implications for the layer stratigraphy. A preliminary result of our modelling is that the shape factor of the horizontal velocity increases at $150-200 \mathrm{~km}$ from Summit as a result of the increased divergence in that area, which also causes the bottom temperatures to increase (the model is described in "Mass balance" in the previous section). This implies enhanced ice deformation in the bottom layers, which is expected to cause annual layers to be dragged down in this region. Dahl-Jensen and others (1997) compared observed radar reflection layers with modelled annual layers. Their model did not take into account effects from divergence of the flow, and at $150-200 \mathrm{~km}$ from GRIP the observed internal layers stacked up to $200 \mathrm{~m}$ deeper in the ice than the layers predicted by their model. This is within the area with increased divergence. They attributed the dip of the observed layers to bottom melting. Bottom melting would also drag annual layers down. The flow pattern in the region with increased divergence affects the downstream stratigraphy. If we assume that ice moves with a constant surface velocity as observed at NorthGRIP, a rough estimate is that at NorthGRIP, which is $120-170 \mathrm{~km}$ downstream, ice older than 90000 years is affected so that it exhibits thicker annual layers than expected from the local flow pattern. This could contribute to making the deep ice younger than expected in the NorthGRIP core (Dahl-Jensen and others, 2002).

\section{Mass balance: our result confirms previous estimates}

The method used to determine the mass balance has been applied to other locations on the Greenland ice sheet (e.g. Reeh and Gundestrup, 1985; Hvidberg and others, 1997b). The method requires accurate surface velocity and strainrate data. At NorthGRIP, the uncertainty of the velocity is $1 \%$, but the sum of the surface strain rates has an uncertainty of $14 \%$. Our calculation of principal strain rates does not take into account that the ridge is not ideally symmetrical over the strain-net area, and that the ridge could be migrating at present. These effects may contribute to the uncertainty of the strain rates. It is not possible, however, to analyze the data for the stability of the ridge before the bottom conditions are known, thereby providing better constraints on the vertical distribution of horizontal velocity.

Our result shows that the Greenland ice sheet is close to mass balance at NorthGRIP. The result confirms other estimates of ice-thickness change. Repeated airborne laseraltimeter surveys over the Greenland ice sheet yield an average thickening rate between 1994 and 1999 of $<0.010 \mathrm{~m} \mathrm{a}^{-1}$ in the high-elevation areas north of $70^{\circ} \mathrm{N}$ (Krabill and others, 2000). Comparison of ice flux across the $2000 \mathrm{~m}$ contour line with the total snow accumulation within this perimeter has been used to estimate the ice-thickening rates over the past few decades in regions in the high-elevation area of the Greenland ice sheet (Thomas and others, 2000). In that study, the region west of the ridge at NorthGRIP has an average thickening rate of $-0.051 \pm 0.017 \mathrm{~m} \mathrm{a}^{-1}$, while the area east of the ridge has an average thickening rate of $+0.021 \pm 0.006 \mathrm{~m} \mathrm{a}^{-1}$. This is consistent with our result of NorthGRIP being close to steady state. 


\section{GONGLUSION}

We present results of a GPS survey along the north-northwest ridge on the Greenland ice sheet near NorthGRIP, and use these to determine strain rates and local mass balance. Our results show that the ice flow along the northnorthwest ridge is highly divergent, and flows with an almost constant surface velocity of $1.329 \pm 0.015 \mathrm{~m} \mathrm{a}^{-1}$ along the ridge. Ice is compressed longitudinally to the ridge, but is stretched horizontally transverse to the ridge. Estimated surface strain rates are $\dot{\varepsilon}_{1}=(-0.4 \pm 0.6) \times 10^{-5} \mathrm{a}^{-1}$ (longitudinal) and $\dot{\varepsilon}_{2}=(7.1 \pm 0.6) \times 10^{-5} \mathrm{a}^{-1}$ (transverse). The divergence increases at $120-170 \mathrm{~km}$ upstream from NorthGRIP, and the resulting slowing-down of the ice could affect annual layer thickness in ice older than 90000 years in the bottom part of the NorthGRIP ice core.

Our mass-balance calculations revealed that the Greenland ice sheet is in local mass balance at NorthGRIP. Allowing for the fact that basal temperatures may be close to pressure-melting point, and assuming a sliding velocity of $50 \%$ of the surface velocity, the average thickening rate is estimated to be $\partial H / \partial t=0.00 \pm 0.04 \mathrm{~m} \mathrm{a}^{-1}$. When we assume no sliding or melting, the rate is $\partial H / \partial t=0.01 \pm 0.04 \mathrm{~m} \mathrm{a}^{-1}$, i.e. no significant difference. Our estimated thickening rate is consistent with that measured by repeated airborne laser (Krabill and others, 2000).

\section{AGKNOWLEDGEMENTS}

The NorthGRIP project is organized by the Department of Geophysics at the Niels Bohr Institute, University of Copenhagen. It is supported by the National Science Foundations of Denmark, Belgium, France, Germany, Japan, Sweden, Switzerland and the United States of America.

\section{REFERENGES}

Dahl-Jensen, D. and 9 others. 1997. A search in north Greenland for a new icecore drill site. 7. Glaciol., 43(144), 300-306.

Dahl-Jensen, D. and 8 others. 2002. The NorthGRIP deep drilling program. Ann. Glaciol., 35 (see paper in this volume).

Ekholm, S. 1996. A full coverage, high resolution topographic model of Greenland computed from a variety of digital elevation data. 7. Geophys. Res., 101(B10), 21,961-21,972.

Grinsted, A. and D. Dahl-Jensen. 2002. A Monte Carlo-tuned model of the flow in the NorthGRIP area. Ann. Glaciol., 35 (see paper in this volume).

Hvidberg, C. S. 1996. Steady-state thermomechanical modelling of ice flow near the centre of large ice sheets with the finite-element technique. Ann. Glaciol., 23, 116-123.

Hvidberg, C. S., D. Dahl-Jensen and E. D. Waddington. 1997a. Ice flow between the GRIP and GISP2 boreholes in central Greenland. $\mathcal{F}$ Geophys. Res., 102(C12), 26,851-26,859.

Hvidberg, C. S., K. Keller, N. S. Gundestrup, C. C. Tscherning and R. Forsberg. 1997b. Mass balance and surface movement of the Greenland ice sheet at Summit, central Greenland. Geophys. Res. Lett., 24(18), 2307-2310.

Krabill, W. and 9 others. 2000. Greenland ice sheet: high-elevation balance and peripheral thinning. Science, 289(5478), 428-430.

Paterson, W. S. B. 1994. The physics of glaciers. Third edition. Oxford, etc., Elsevier.

Reeh, N. 1988. A flow-line model for calculating the surface profile and the velocity, strain-rate, and stress fields in an ice sheet. f. Glaciol., 34(116), 46-54.

Reeh, N. and N. S. Gundestrup. 1985. Mass balance of the Greenland ice sheet at Dye 3. F. Glaciol., 31(108), 198-200.

Thomas, R. and 6 others. 2000. Mass balance of the Greenland ice sheet at high elevations. Science, 289(5478), 426-428. 